\title{
Anaerobic and Aerobic Enzyme Activities in Human Skeletal Muscle from Children and Adults
}

\author{
JAN J. KACZOR, WIESLAW ZIOLKOWSKI, JERZY POPINIGIS, AND MARK A. TARNOPOLSKY \\ Department of Biochemistry [J.J.K., W.Z., J.P.], J. Sniadecki University School of Physical Education and \\ Sport, 80-336 Gdansk, Wiejska 1, Poland; and Departments of Pediatrics [J.J.K., M.A.T.] and Medicine \\ [M.A.T.], McMaster University, Hamilton, Ontario, Canada L8N $3 Z 5$
}

\begin{abstract}
ABST
Literature has shown that children have lower anaerobic
capacity and oxidize more lipids during aerobic activity com-
pared with adults. The purpose of the present study was to
examine the effects of age on the activity of marker enzymes for
anaerobic and aerobic metabolism in human skeletal muscle
from relatively sedentary children and adults. The m. obliquus
internus abdominis was analyzed for anaerobic [creatine kinase,
adenylate kinase, and lactate dehydrogenase (LDH)] and aerobic
(carnitine palmitoyltransferase and 2 -oxoglutarate dehydroge-
nase) enzyme activities in 32 male individuals. The subjects were
divided into two groups: children $(3-11 \mathrm{y} ; n=20)$ and adults
(29-54 y; $n=12)$. LDH activity was higher in adults $(118.2 \pm$
$20.1)$ compared with children $(27.8 \pm 10.1) \mu$ mol $\cdot$ min ${ }^{-1} \cdot \mathrm{g}-1$
wet weight $(p<0.0002)$. Creatine kinase activity was $28 \%(p<$
$0.0003)$ lower in children than in adults, and adenylate kinase
activity was $20 \%(p<0.006)$ lower in children than in adults. In
addition, we found higher 2 -oxoglutarate dehydrogenase activity
in adults compared with children $(p<0.04)$, with no effect of age
\end{abstract}
The functional characteristics of human skeletal muscle are partially dependent on fiber type; however, modifications to the nature and the capacity of the energy-delivering metabolic pathways can occur independent of fiber type. It is widely known that metabolic enzymes in skeletal muscle have the ability to respond to physiologic stimuli such as exercise (1-4), as well as pathologic processes such as muscular dystrophy, acute respiratory failure, mitochondrial myopathy, denervation, and inactivity (5-9). Although there is some controversy regarding fiber type differences between children and adults (10-13), there are only minor increases in the proportion of type II fibers with age (10-12), with no difference in ultrastructure (13). Moreover, there is still disagreement over the

Received April 16, 2004; accepted July 23, 2004.

Correspondence: Mark A. Tarnopolsky, M.D., Ph.D., Department of Pediatrics and Medicine, Room 4U4, McMaster University Medical Center, 1200 Main Street W., Hamilton, Ontario, Canada, L8N 3Z5; e-mail: tarnopol@mcmaster.ca

Supported, in part, by a grant from Polish State Committee for Scientific Research.

DOI: 10.1203/01.PDR.0000150799.77094.DE on carnitine palmitoyltransferase activity (NS). When samples were expressed relative to protein content, only LDH activity remained significantly lower in children compared with adults ( $p$ $<0.0001)$. In conclusion, the lower LDH activity observed in children compared with adults may partially explain decreased anaerobic and lactate generation capacity of the children studied. However, the mechanisms for the relatively deficient anaerobic enzyme activities of children are not clear. (Pediatr Res 57: 331-335, 2005)
$\mathbf{A K}$, adenylate kinase
Abbreviations
CK, creatine kinase
CPT, carnitine palmitoyltransferase
$\mathbf{C V}$, coefficient of variation
LDH, lactate dehydrogenase
OGDH, 2-oxoglutarate dehydrogenase
PFK, phosphofructokinase

effect of age on the enzymatic capacity of skeletal muscle, particularly during the maturation from the pediatric to the adult age group.

It has been reported that phosphofructokinase (PFK) was 3 -fold lower in the skeletal muscle of children (11-13 y) compared with adults (24-52 y); however, succinate dehydrogenase activity was not significantly altered by age $(11,14)$. Other studies that have examined anaerobic enzyme activity in children have reported lower glycolytic [PFK, lactate dehydrogenase (LDH)] and higher aerobic (succinate dehydrogenase, fumarase) enzyme activities in children compared with younger adults $(14,15)$. In contrast, one report demonstrated similar activity of PFK, LDH, and citrate synthase in children (13-15 y) compared with adults (22-42 y) (16).

Children's lower glycolytic enzyme capacity may also lead to decreased anaerobic power. Furthermore, a 2- to 3-fold lower blood lactate concentration after both submaximal and maximal exercise in children compared with untrained and trained adults $(10,17-19)$ is consistent with lower anaerobic 
enzyme activity in children. These data suggest that age-related differences in anaerobic performance, from childhood to adulthood, may be attributed to the enzyme activities involved in anaerobic pathways in skeletal muscle. In addition to the glycolytic pathway, the creatine kinase (CK) and adenylate kinase (AK) pathways contribute to anaerobic energy transduction, but to our knowledge, AK enzyme activity has not been reported in children compared with adults.

The effect of pediatric to adult maturation on the maximal activity of aerobic enzymes is unclear $(16,20)$, and no studies have measured 2-oxoglutarate dehydrogenase (OGDH), which is the rate-limiting enzyme of the tricarboxylic acid cycle. Similarly, there have been no reports of carnitine palmitoyltransferase (CPT) activity in children compared with adults, although children are known to oxidize proportionately more total fat than adults during submaximal endurance exercise (21). CPT isoenzymes are involved in the transfer of longchain acyl groups from the cytosol into the mitochondrial matrix. In addition, because CPT deficiency is the most common cause of exercise-induced myoglobinuria (22-24), it is important to determine whether there are age-related changes in skeletal muscle CPT activity.

The purpose of the present study was to examine the effects of age on nonglycolytic anaerobic enzyme capacity (CK and $\mathrm{AK}$ ), an enzymatic marker enzyme for lactate generation (LDH), mitochondrial lipid transport (CPT), and the ratelimiting enzyme of the tricarboxylic acid cycle (OGDH) from human skeletal muscle obtained from healthy but relatively sedentary children and adults. Our hypotheses were that the activity of CK, AK, and LDH enzymes would be lower in children versus adults. Furthermore, we hypothesized that the activity of CPT would be higher and OGDH would be similar in children compared with adults.

\section{METHODS}

Thirty-two sedentary white male individuals aged 3-54 y participated in this study. Adult participants and the parents of child participants provided informed written voluntary consent for the investigation. The experimental protocol was approved by the Local Ethics Committee of the Medical University of Gdansk, and all data collection and analysis were completed there. Samples of the obliquus internus abdominis muscle were collected from patients who underwent hernia surgery at the Medical University Clinic in Gdansk. The current literature reports that a hernia has no effect on enzyme activity (25) in the adjacent skeletal muscle. Furthermore, any potential effects of a hernia on enzyme activity should be similar between children and adults. Individuals with neuromuscular or other chronic diseases that are known to lead to changes in muscle structure and function were excluded. The individuals were divided into two groups: children (3-11 y; $n=20)$ and adults (29-54 y; $n=12)$.

Muscle samples and maximal enzyme activities. The muscle samples $(30-50 \mathrm{mg}$ ) were dissected free of visible fat and connective tissue, weighed, immediately frozen in liquid nitrogen, and then stored for $6 \mathrm{mo}$ at $-80^{\circ} \mathrm{C}$ until analysis. It has been reported that the range of fiber distribution in the obliquus internus abdominis muscle is 55-58\% type I, 15-23\% type IIA, and 21-28\% type IIB in humans (aged 24-54 y) (26). Muscle specimens then were minced and homogenized in a glass-Teflon Porter-Elvenhejm homogenizer in 1:25 (wt/vol) dilution of buffer that contained $50 \mathrm{mM}$ of potassium phosphate, 1 $\mathrm{mM}$ of EDTA, $1 \mathrm{mM}$ of DTT, and $0.05 \%$ Triton $\mathrm{X}-100$ at $\mathrm{pH} 7.4$. The homogenates then were centrifuged at $600 \times g$ at $4^{\circ} \mathrm{C}$ for $10 \mathrm{~min}$. The resulting supernatant produced an enzyme sample that was decanted and assayed for $\mathrm{CK}, \mathrm{AK}, \mathrm{LDH}, \mathrm{OGDH}$, and CPT activity. The maximum rates of the enzyme activities were measured spectrophotometrically using the Cecil 9200 Super Aquarius spectrophotometer (Cambridge, England) with thermostatic holder at $30^{\circ} \mathrm{C}$. All of the assays were performed in duplicate.
The activity of CK (EC 2.7.3.2) was assessed using Test Kit 45 (Sigma Chemical Co., St. Louis, MO; CK, AK, glucose-6 phosphate dehydrogenase coupled assay). The reaction was started with $10 \mu \mathrm{L}$ of diluted supernatant in potassium phosphate buffer 1:5 at $\mathrm{pH}$ 7.4. The increase in absorbance at $340 \mathrm{~nm}$ was followed for $3 \mathrm{~min}$. The intra-assay coefficient of variation (CV) was 6.6\%.

The maximal activity of AK (EC 2.7.4.3) was measured according to Russell et al. (27). The assay medium contained $50 \mathrm{mM}$ of Tris- $\mathrm{HCl}$ at $\mathrm{pH} 7.6$, $13 \mathrm{mM}$ of $\mathrm{MgSO}_{4}, 43 \mathrm{mM}$ of KCl, $1 \mathrm{mM}$ of DTT, $0.3 \mathrm{mM}$ of Phospho (enol) pyruvic acid (PEP) in the presence of $0.27 \mathrm{U}$ of pyruvate kinase, $1.5 \mathrm{U}$ of $\mathrm{LDH}$, $230 \mu \mathrm{M}$ of $\mathrm{NADH}, 1.3 \mathrm{mM}$ of ATP, $1.3 \mathrm{mM}$ of AMP, and $10 \mu \mathrm{L}$ of supernatant. The substrates NADH, ATP, and AMP were added immediately before the measurement of the enzyme activity, and the reaction was started. The final volume in the cuvette was $1000 \mu \mathrm{L}$. The decrease in absorbance at $340 \mathrm{~nm}$ was followed for $15 \mathrm{~min}$. The intra-assay CV was $4.5 \%$.

The activity of LDH (EC 1.1.1.27) was measured according to Leger and Taylor (28). The assay medium contained $50 \mathrm{mM}$ of potassium phosphate at $\mathrm{pH} 7.2,1 \mathrm{mM}$ of EDTA, $100 \mu \mathrm{M}$ of NADH, $2.1 \mathrm{mM}$ of pyruvate, and $10 \mu \mathrm{L}$ of supernatant. The substrates NADH and pyruvate were added immediately before the measurement of the enzyme activity, and the reaction was started. The final volume in the cuvette was $1000 \mu \mathrm{L}$. The decrease in absorbance at $340 \mathrm{~nm}$ was followed for $3 \mathrm{~min}$. The intra-assay CV was $5.2 \%$.

OGDH (EC 1.2.4.2) activity was determined according to Cooney et al. (29) by measuring the production of NADH when 2-oxoglutarate is converted to succinyl-CoA. The reaction mixture was composed of $100 \mathrm{mM}$ of Tris- $\mathrm{HCl}$ at $\mathrm{pH} 7.4,250 \mathrm{mM}$ of mannitol, $10 \mathrm{mM}$ of KCl, $5 \mathrm{mM}$ of $\mathrm{MgCl}_{2}, 1 \mathrm{mM}$ of DTT, $10 \mathrm{mM}$ of potassium phosphate with $0.05 \%$ Triton X-100, $2 \mathrm{mM}$ of $\mathrm{NAD}^{+}, 0.63 \mathrm{mM}$ of $\mathrm{CoASH}$, and $10 \mathrm{mM}$ of 2-oxoglutarate. A total of $80 \mu \mathrm{L}$ of supernatant and the substrates $\mathrm{NAD}^{+}$and $\mathrm{CoASH}$ were added immediately before the measurement of the enzyme activity, and the reaction was started with 2-oxoglutarate. The final volume in the cuvette was $1000 \mu \mathrm{L}$. The increase in absorbance at $340 \mathrm{~nm}$ was followed for $5 \mathrm{~min}$. The intra-assay CV was $3.1 \%$.

The CPT (total CPT I and CPT II; EC 2.3.1.21.) activity was measured in the supernatant, using methods described by Biber et al. (30) and Zammit and Newsholm (31). The reaction mixture was composed of $60 \mathrm{mM}$ of Tris $\mathrm{HCl}$ at $\mathrm{pH} 8.0,1.5 \mathrm{mM}$ of EDTA with $0.05 \%$ Triton X-100 and $0.25 \mathrm{mM} 5,5$ '-Dithiobis (2-nitrobenzoic acid), and $1.67 \mathrm{mM}$ of carnitine. A total of $100 \mu \mathrm{L}$ of supernatant and the substrates 5,5'-Dithiobis (2-nitrobenzoic acid) and carnitine were added immediately before the measurement of the enzyme activity. The reaction was started by the addition of $0.025 \mathrm{mM}$ of palmitoyl-CoA. The final volume in the cuvette was $1000 \mu \mathrm{L}$. The increase in absorbance at $412 \mathrm{~nm}$ was followed for 5 $\min$. The intra-assay $\mathrm{CV}$ was $3.9 \%$. The analysis of protein content was performed in the supernatant according to Lowry et al. (32).

Statistical analysis. Statistical analysis was performed using a software package (Statistica, V. 5.0; Tulsa, OK) in which differences between the means were tested using an unpaired $t$ test. The results are expressed as mean \pm SD, and the statistical significance was established at $p<0.05$.

\section{RESULTS}

\section{Enzyme Activities Expressed as $\mu \mathrm{mol} \cdot \min ^{-1} \cdot \mathrm{g}^{-1}$ wet weight}

Anaerobic enzymes. The range of maximal LDH activity in children was $14.0-51.3$ and in adults was 77.4-146.7 $\mu \mathrm{mol}$. $\min ^{-1} \cdot \mathrm{g}^{-1}$ wet weight (Fig. 1A). The LDH activity was 4 -fold higher in adults compared with children $(p<0.0002)$.

The range of maximal activity of $\mathrm{AK}$ in children was 59.3-98.1 and in adults was $69.0-117.4 \mu \mathrm{mol} \cdot \mathrm{min}^{-1} \cdot \mathrm{g}^{-1}$ wet weight. The AK activity was $20 \%$ lower in children compared with adults $(p<0.006$; Fig. $1 A)$.

The range of maximal CK activity in the skeletal muscle of children was 346.7-592.4 and of adults was 496.0-715.6 $\mu \mathrm{mol} \cdot \min ^{-1} \cdot \mathrm{g}^{-1}$ wet weight. The CK activity was $28 \%$ lower in children compared with adults $(p<0.0005$; Fig. $1 B)$.

Aerobic enzymes. The range of maximal activity of OGDH in children was $0.48-1.50$ and in adults was $0.66-1.60 \mu \mathrm{mol}$. $\min ^{-1} \cdot \mathrm{g}^{-1}$ wet weight (Fig. 2). OGDH activity was lower in children compared with adults ( $p<0.04$; Fig. 2 ). The range of 
A

\section{LDH and AK activity}

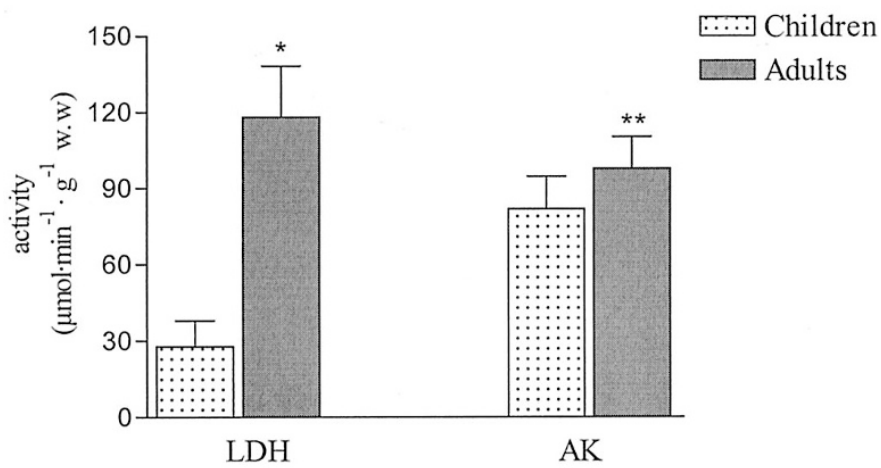

B

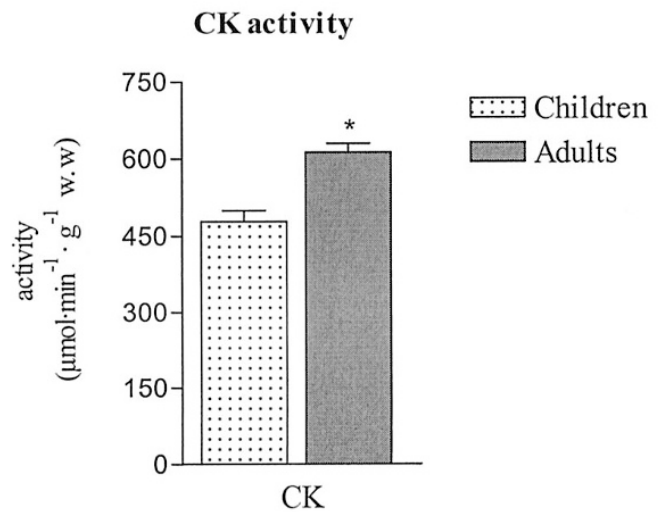

Figure 1. (A) The effect of age on muscle LDH and AK activity. The results are statistically different $(* p<0.0002, * * p<0.006)$ in children $(n=16) v s$ adults $(n=12)$, respectively. $(B)$ The effect of age on the CK activity in both tested groups. *Significantly different $(p<0.0005)$ from children $(n=20)$ to adult $(n=12)$ groups. The $\mathrm{LDH}, \mathrm{AK}$, and $\mathrm{CK}$ activities are expressed as mean $\pm \mathrm{SD} \mu \mathrm{mol} \cdot \min ^{-1} \cdot \mathrm{g}^{-1}$ wet weight.

\section{OGDH and CPT activity}

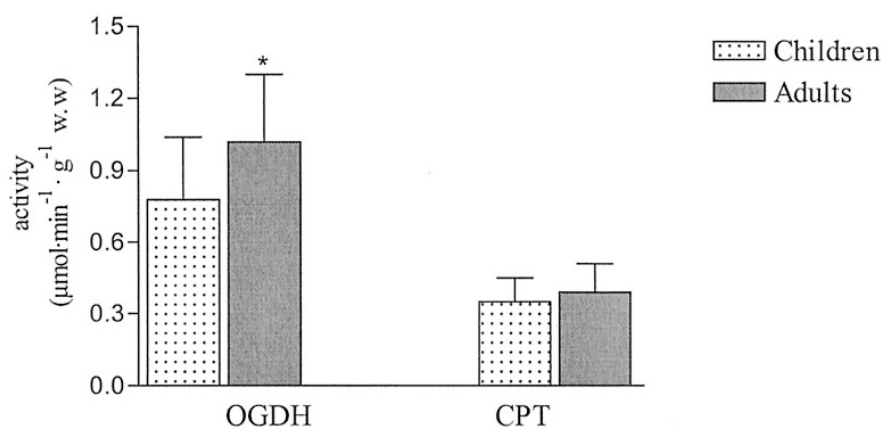

Figure 2. The effect of age on muscle OGDH and CPT activity. *Significantly different $(p<0.04)$ OGDH activity between children $(n=19)$ and adults $(n=12)$. There was no difference in CPT activity between children $(n=$ $17)$ and adults $(n=12)$. The results are expressed as mean \pm SD $\mu \mathrm{mol}$. $\min ^{-1} \cdot \mathrm{g}^{-1}$ wet weight.

maximal activity of total CPT in children was $0.15-0.51$ and in adults was $0.23-0.61 \mu \mathrm{mol} \cdot \mathrm{min}^{-1} \cdot \mathrm{g}^{-1}$ wet weight (NS; Fig. 2).

The CPT/LDH ratio of enzyme activities in skeletal muscle was significantly higher in children versus adults (3-fold; $p<$ 0.0002). The ratio of CPT/OGDH had a tendency to be higher $(16 \%)$ in children compared with adults, but the difference did not reach the level of significance $(p=0.16$; Table 1$)$.
Table 1. $C P T / L D H$ and $C P T / O G D H$ ratio of enzyme activities in skeletal muscle

\begin{tabular}{lcc}
\hline Ratio & $\begin{array}{c}\text { Children } \\
(n=16)\end{array}$ & $\begin{array}{c}\text { Adults } \\
(n=12)\end{array}$ \\
\hline CPT/LDH & $0.0132 \pm 0.0048$ & $0.0034 \pm 0.0012 *$ \\
CPT/OGDH & $0.46 \pm 0.13$ & $0.39 \pm 0.09$ \\
\hline
\end{tabular}

The age-dependent changes on CPT/LDH and CPT/OGDH ratios measured in skeletal muscle of children and adults.

* Children $v s$ adults $p<0.0002$.

Protein content. Mean total protein content was $21 \%$ lower in children (110.6 $\pm 17.4 \mathrm{mg} / \mathrm{g}$ wet weight; $n=16)$ than in adults $(133.4 \pm 17.0 \mathrm{mg} / \mathrm{g}$ wet weight; $n=11 ; p<0.005)$.

\section{Enzyme Activities Expressed as $\mathbf{n m o l} \cdot \mathbf{m i n}^{-1} \cdot \mathrm{mg}^{-1}$ protein}

When the activities of skeletal muscle CK, AK, OGDH, and CPT were expressed relative to total protein content, there were no longer significant differences between children and adults (Table 2). Only LDH activity remained significantly different between the two groups when expressed relative to protein content, with the children 3.5 -fold lower than the adults $(p<0.0001$; Table 2).

\section{DISCUSSION}

To date, there has been a paucity of information concerning the potential differences in human skeletal muscle metabolic enzyme capacity between children and adults. To our knowledge, the current data represent the first report of AK, CPT, and OGDH enzyme activity in children compared with adults.

The most striking age-related changes were seen with LDH activity. Children were shown to have 3.5-fold lower LDH activity compared with adults, which is consistent with the findings of other groups $(10,15)$. However, it should be noted that one study found no differences in LDH activity (16), but the children were 13-15 y and had most likely begun or had finished sexual maturation. A 3-fold higher PFK activity (the rate-limiting enzyme of glycolysis) (33) has been previously reported in adults compared with children $(11,14)$. Together, these findings are consistent with studies showing lower blood $(17-19,34,35)$ and muscle (18) lactate concentration in children after exercise, compared with adults. In addition, it was found that boys $(9-12$ y) recover faster than men (19-23 y) from high-intensity short-term exercise, and it was suggested that a lower reliance on glycolysis during the Wingate anaerobic test led to decreased acidosis in boys (36). Moreover, it has been reported that venous blood $\mathrm{pH}$ was less acidic (7.32) in 10-y-old children compared with 25-y-old adults (7.18) (37). Finally, blood lactate and base excess were significantly lower in boys versus young adults and after repeated supramaximal exercise (38).

Our findings of lower CK and AK activity in children further support that children have lower anaerobic capacity compared with adults. However, others have found no difference in CK activity in skeletal muscle of children versus adults $(15,16)$. The absolute values for AK activity of our adult subjects is consistent with other reports $(39,40)$, and to our knowledge, 
Table 2. The effect of age on $C K, A K, L D H, O G D H$, and CPT enzymes activity in the obliquus internus abdominis muscle measured in children and adults

\begin{tabular}{|c|c|c|c|c|c|}
\hline Group & $\mathrm{CK}$ & $\mathrm{AK}$ & $\mathrm{LDH}$ & OGDH & $\mathrm{CPT}$ \\
\hline Children $(n=16)$ & $4404 \pm 820$ & $742 \pm 167$ & $247 \pm 65$ & $7.6 \pm 2.1$ & $3.0 \pm 0.8$ \\
\hline Adults $(n=11)$ & $4664 \pm 565$ & $738 \pm 104$ & $886 \pm 141 *$ & $7.8 \pm 1.7$ & $3.0 \pm 0.9$ \\
\hline
\end{tabular}

Enzyme activities are expressed as $\mathrm{nmol} \cdot \mathrm{min}^{-1} \cdot \mathrm{mg}^{-1}$ protein.

* Children $v s$ adults $p<0.0001$.

this is the first report of this enzyme's activity in children compared with adults. Although our data showed that CK and AK values were no longer different from adult values when expressed per milligram of total protein, we believe that power output is likely a function of total muscle mass and not protein content per se. Consequently, enzyme activities expressed relative to net muscle weight likely correlate better with indices of muscle function.

The activity of OGDH in skeletal muscle is rate limiting in the tricarboxylic acid cycle. In addition, it seems that the enzyme is fully activated during exercise (41-43). The absolute OGDH activity values measured in skeletal muscle of adults in the present study was similar to those previously reported $(42,44)$. However, to our knowledge, the activity of this enzyme has not yet been reported in children. We found a marginally (25\%) lower OGDH activity in children compared with adults. In contrast, studies have found significantly higher NADP-isocitrate dehydrogenase, fumarase, and malate dehydrogenase in skeletal muscle of pubescent children compared with adults, with no differences in citrate synthase activity (16). In general, little or no differences in aerobic enzyme capacity are consistent with other reports that aerobic power is similar in children and adults $(10,45)$.

The oxidation of long-chain fatty acids in the mitochondria plays an important role in aerobic energy production, in skeletal muscle. Long-chain fatty acids are shuttled across the mitochondrial membrane by two CPTs (CPT I and CPT II). There are no published comparative studies of CPT activity in healthy children and adults. In the current study, we did not find any age-related changes in CPT activity in children compared with adults. This finding is consistent with studies showing no differences in enzyme activities of fatty acid metabolism (acetoacetyl-CoA thiolase and 3-hydroxyacyl dehydrogenase) in pubescent children compared with young adults (16). However, it has been shown that children use proportionally more fat and less carbohydrate than adults during exercise performed at the same relative intensity $(21,34,46)$. Recently, higher rates of total fat oxidation were reported before and after exercise in children versus adults, even when fed carbohydrate (21). The higher fat oxidation in boys may be a "default" mechanism as a result of an underdeveloped glycogenolysis and/or glycolytic system (21). Moreover, the CPT/OGDH ratio of enzyme activities in skeletal muscle tended to be higher $(16 \%)$ in children versus young adults, but the differences did not reach statistical significance $(p=0.16)$. This finding may suggest that there is higher oxidation of fatty acids than other substrates by mitochondria in children compared with adults. For example, the CPT/LDH ratio was 3-fold higher in children compared with adults in the current study. It is also possible that there are age-related differences in the ratio of CPT I:CPT II enzyme activities; however, our assay did not distinguish between the two.

Some studies have found a higher proportion of type I muscle fibers in children versus adults $(11,12)$, whereas one group did not show these findings (13). Even if there is a greater proportion of type I muscle fibers in children, there does not seem to be a strong correlation between fiber type composition and enzyme activity in skeletal muscle (47). Consequently, differences in fiber type cannot explain the markedly lower LDH activity found in children compared with adults.

The potential mechanism(s) for lower total protein in the skeletal muscle of children versus adults could relate to higher total water and fat-free body mass content in children $(10,14,48)$. This is an important observation because it may explain some of the discrepancies in current literature with respect to the effect of age on muscle enzyme activity. After expressing enzyme data relative to total protein, only $\mathrm{LDH}$ activity remained different between the two groups (higher in adults versus children).

In conclusion, the activities of the anaerobic enzymes CK, $\mathrm{AK}$, and LDH in children were lower than in adults. The lower anaerobic performance in children versus adults might be due to their smaller muscle mass, lower protein content, or a lower percentage of fast-twitch muscle fibers. However, children's statistically significant lower LDH activity is likely to be the major factor of their decreased anaerobic performance. The OGDH activity measured in our subjects was slightly lower, and CPT activity was similar for children versus adults, but when the data were expressed relative to protein content, there was no significant difference. The ratio of CPT/LDH was much greater in children and the ratio of CPT/OGDH tended to be higher. Together, these results suggest that children have a greater ability to oxidize lipids during exercise. Overall, the mechanisms behind the enzymatic differences reported here in children and adults are not clear.

Acknowledgments. We are indebted to Profs. J. Stoba and Z. Wajda from Surgical Clinics of Medical University of Gdansk, as well as to their surgeon staffs, for invaluable aid in obtaining muscle samples. Sadly, Professor J. Popinigis passed away during the preparation of this manuscript; his contribution to the design and data collection in the current study was invaluable.

\section{REFERENCES}

1. Holloszy JO 1967 Biochemical adaptations in muscle. Effects of exercise on mitochondrial oxygen uptake and respiratory enzyme activity in skeletal muscle. J Biol Chem 242:2278-2282 
2. Bass A, Vondra K, Rath R, Vitek V, Teisinger J, Mackova E, Sprynarova S, Malkovska M 1976 Enzyme activity patterns of energy supplying metabolism in the quadriceps femoris muscle (vastus lateralis): sedentary men and physically active men of different performance levels. Pflugers Arch 361:169-173

3. Costill DL, Daniels J, Evans W, Fink W, Krahenbuhl G, Saltin B 1976 Skeleta muscle enzymes and fiber composition in male and female track athletes. J Appl Physiol 40:149-154

4. Chi MM, Hintz CS, Coyle EF, Martin WH 3rd, Ivy JL, Nemeth PM, Holloszy JO Lowry OH 1983 Effects of detraining on enzymes of energy metabolism in individual human muscle fibers. Am J Physiol 244:C276-C287

5. Haslett JN, Sanoudou D, Kho AT, Bennett RR, Greenberg SA, Kohane IS, Beggs AH, Kunkel LM 2002 Gene expression comparison of biopsies from Duchenne muscular dystrophy (DMD) and normal skeletal muscle. Proc Natl Acad Sci USA 99:1500015005

6. Bertorini T, Yeh YY, Trevisan C, Stadlan E, Sabesin S, DiMauro S 1980 Carnitine palmityl transferase deficiency: myoglobinuria and respiratory failure. Neurology 30:263-271

7. Chang CW, Huang SF 2001 Varied clinical patterns, physical activities, muscle enzymes, electromyographic and histologic findings in patients with post-polio syndrome in Taiwan. Spinal Cord 39:526-531

8. Deschauer M, Muller T, Wieser T, Schulte-Mattler W, Kornhuber M, Zierz S 2001 Hearing impairment is common in various phenotypes of the mitochondrial DNA A3243G mutation. Arch Neurol 58:1885-1888

9. Seedorf U, Leberer E, Kirschbaum BJ, Pette D 1986 Neural control of gene expression in skeletal muscle. Effects of chronic stimulation on lactate dehydrogenase isoenzymes and citrate synthase. Biochem J 239:115-120

10. Eriksson BO 1972 Physical training, oxygen supply and muscle metabolism in 11-13-year old boys. Acta Physiol Scand Suppl 384:1-48

11. Gollnick PD, Armstrong RB, Saubert CW 4th, Piehl K, Saltin B 1972 Enzyme activity and fiber composition in skeletal muscle of untrained and trained men. J Appl Physiol 33:312-319

12. Lexell J, Sjostrom M, Nordlund AS, Taylor CC 1992 Growth and development of human muscle: a quantitative morphological study of whole vastus lateralis from childhood to adult age. Muscle Nerve 15:404-409

13. Bell RD, MacDougall JD, Billeter R, Howald H 1980 Muscle fiber types and morphometric analysis of skeletal muscle in six-year-old children. Med Sci Sports Exerc 12:28-31

14. Eriksson BO, Gollnick PD, Saltin B 1973 Muscle metabolism and enzyme activities after training in boys 11-13 years old. Acta Physiol Scand 87:485-497

15. Berg A, Kim SS, Keul J 1986 Skeletal muscle enzyme activities in healthy young subjects. Int J Sports Med 7:236-239

16. Haralambie G 1982 Enzyme activities in skeletal muscle of 13-15 years old adolescents. Bull Eur Physiopathol Respir 18:65-74

17. Wirth A, Trager E, Scheele K, Mayer D, Diehm K, Reischle K, Weicker H 1978 Cardiopulmonary adjustment and metabolic response to maximal and submaxima physical exercise of boys and girls at different stages of maturity. Eur J Appl Physiol Occup Physiol 39:229-240

18. Eriksson BO, Karlsson J, Saltin B 1971 Muscle metabolites during exercise in pubertal boys. Acta Paediatr Scand Suppl 217:154-157

19. Williams JR, Armstrong N, Kirby BJ 1990 The $4 \mathrm{mM}$ blood lactate level as an index of exercise performance in 11-13 year old children. J Sports Sci 8:139-147

20. Taylor DJ, Kemp GJ, Thompson CH, Radda GK 1997 Ageing: effects on oxidative function of skeletal muscle in vivo. Mol Cell Biochem 174:321-324

21. Timmons BW, Bar-Or O, Riddell MC 2003 Oxidation rate of exogenous carbohydrate during exercise is higher in boys than in men. J Appl Physiol 94:278-284

22. Scholte HR, Jennekens FG, Bouvy JJ 1979 Carnitine palmitoyltransferase II deficiency with normal carnitine palmitoyltransferase I in skeletal muscle and leucocytes. J Neurol Sci 40:39-51

23. Layzer RB, Havel RJ, McIlroy MB 1980 Partial deficiency of carnitine palmitoyltransferase: physiologic and biochemical consequences. Neurology 30:627-633

24. Zierz S, Neumann-Schmidt S, Jerusalem F 1993 Inhibition of carnitine palmitoyltransferase in normal human skeletal muscle and in muscle of patients with carnitine palmitoyltransferase deficiency by long- and short-chain acylcarnitine and acylcoenzyme A. Clin Investig 71:763-769
25. Abou-Hatab K, O'Mahony MS, Patel S, Carey D, Woodhouse K 2000 Plasma esterase activities in young and old patients undergoing open inguinal hernia repair. Arch Gerontol Geriatr 31:193-198

26. Haggmark T, Thorstensson A 1979 Fibre types in human abdominal muscles. Acta Physiol Scand 107:319-325

27. Russell PJ Jr, Horenstein JM, Goins L, Jones D, Laver M 1974 Adenylate kinase in human tissue. I. Organ specificity of adenylate kinase isoenzymes. J Biol Chem 249:1874-1879

28. Leger LA, Taylor AW 1982 The chronic effects of continuous and intermittent running upon lactate dehydrogenase activity of heart, fast and slow twitch muscles in the rat. J Physiol (Paris) 78:499-506

29. Cooney GJ, Taegtmeyer H, Newsholme EA 1981 Tricarboxylic acid cycle flux and enzyme activities in the isolated working rat heart. Biochem J 200:701-703

30. Bieber LL, Abraham T, Helmrath T 1972 A rapid spectrophotometric assay for carnitine palmitoyltransferase. Anal Biochem 50:509-518

31. Zammit VA, Newsholme EA 1979 Activities of enzymes of fat and ketone-body metabolism and effects of starvation on blood concentrations of glucose and fat fuels in teleost and elasmobranch fish. Biochem J 184:313-322

32. Lowry OH, Rosebrough HJ, Farr AL, Randall RJ 1951 Protein measurement with the Folin phenol reagent. J Biol Chem 193:265-275

33. Danforth WH, Lyon JB Jr 1964 Glycogenolysis during tetanic contraction of isolated mouse muscles in the presence and absence of phosphorylase A. J Biol Chem 239:4047-4050

34. Mahon AD, Duncan GE, Howe CA, Del Corral P 1997 Blood lactate and perceived exertion relative to ventilatory threshold: boys versus men. Med Sci Sports Exerc 29:1332-1337

35. Falgairette G, Bedu M, Fellmann N, Van Praagh E, Coudert J 1991 Bio-energetic profile in 144 boys aged from 6 to 15 years with special reference to sexual maturation. Eur J Appl Physiol Occup Physiol 62:151-156

36. Hebestreit H, Mimura K, Bar-Or O 1993 Recovery of muscle power after highintensity short-term exercise: comparing boys and men. J Appl Physiol 74:2875-2880

37. Hebestreit H, Meyer F, Htay-Htay, Heigenhauser GJ, Bar-Or O 1996 Plasma metabolites, volume and electrolytes following 30-s high-intensity exercise in boys and men. Eur J Appl Physiol Occup Physiol 72:563-569

38. Ratel S, Duche P, Hennegrave A, Van Praagh E, Bedu M 2002 Acid-base balance during repeated cycling sprints in boys and men. J Appl Physiol 92:479-485

39. Borges O, Essen-Gustavsson B 1989 Enzyme activities in type I and II muscle fibres of human skeletal muscle in relation to age and torque development. Acta Physiol Scand 136:29-36

40. Larsson L, Sjodin B, Karlsson J 1978 Histochemical and biochemical changes in human skeletal muscle with age in sedentary males, age 22-65 years. Acta Physiol Scand 103:31-39

41. Blomstrand E, Radegran G, Saltin B 1997 Maximum rate of oxygen uptake by human skeletal muscle in relation to maximal activities of enzymes in the Krebs cycle. J Physiol 501:455-460

42. Sun G, Ukkola O, Rankinen T, Joanisse DR, Bouchard C 2002 Skeletal muscle characteristics predict body fat gain in response to overfeeding in never-obese young men. Metabolism 51:451-456

43. Tikkanen HO, Hamalainen E, Sarna S, Adlercreutz H, Harkonen M 1998 Associations between skeletal muscle properties, physical fitness, physical activity and coronary heart disease risk factors in men. Atherosclerosis 137:377-389

44. Ukkola O, Joanisse DR, Tremblay A, Bouchard C $2003 \mathrm{Na}+-\mathrm{K}+-$ ATPase alph 2-gene and skeletal muscle characteristics in response to long-term overfeeding. J Appl Physiol 94:1870-1874

45. Rowland TW, Auchinachie JA, Keenan TJ, Green GM 1987 Physiologic responses to treadmill running in adult and prepubertal males. Int J Sports Med 8:292-297

46. Martinez LR, Haymes EM 1992 Substrate utilization during treadmill running in prepubertal girls and women. Med Sci Sports Exerc 24:975-983

47. Bouchard C, Lesage R, Lortie G, Simoneau JA, Hamel P, Boulay MR, Perusse L, Theriault G, Leblanc C 1986 Aerobic performance in brothers, dizygotic and monozygotic twins. Med Sci Sports Exerc 18:639-646

48. Hewitt MJ, Going SB, Williams DP, Lohman TG 1993 Hydration of the fat-free body mass in children and adults: implications for body composition assessment. Am J Physiol 265:E88-E95 